\author{
ZUZANNA ZBRÓG* \\ Kielce, Polska \\ ORCID ID: https://www.orcid.org/oooo-0oo2-4048-626X
}

Forum Pedagogiczne $10(2020) 1$

Wpłynęło: 30.12 .2019 Zatwierdzono do druku: 18.03.2020 DOI: $10.21697 /$ fp.2020.1.02

\title{
ORGANIZOWANIE ŚRODOWISKA EDUKACYJNEGO SPRZYJAJĄCEGO UJAWNIANIU I ROZWIJANIU KREATYWNOŚCI DZIECIĘCEJ
}

\begin{abstract}
Streszczenie: W artykule zanalizowano najważniejsze czynniki wspierające rozwój umiejętności kreatywnych u dzieci w wieku przedszkolnym i wczesnoszkolnym, które zostały wyłonione na podstawie badań empirycznych z ostatnich kilkunastu lat. Dla jasności wywodu zostały one ujęte $\mathrm{w}$ dwóch grupach: środowisko fizyczne i środowisko pedagogiczne, choć wszystkie przedstawione determinanty wzajemnie się przenikają i uzupełniają. $\mathrm{Na}$ zakończenie zarekomendowano wybrane rozwiązania dla praktyki wczesnej edukacji.
\end{abstract}

Słowa kluczowe: kreatywność; środowisko edukacyjne; wczesna edukacja.

\section{Wprowadzenie}

Na podstawie teorii socjokulturowych Lwa S. Wygotskiego i Jerome’a S. Brunera przyjmuje się, że środowisko edukacyjne może być rozumiane jako „źródło dziecięcych doświadczeń i rekonstrukcji”, jako „środowisko, które zawiera w sobie potencjał sprzyjający aktywności podmiotowej, gdzie dziecko może nabywać doświadczenie $\mathrm{w}$ różnych porządkach rzeczywistości i rekonstruować swoją wiedzę" (Bałachowicz 2018/2019, s. 16-17) ${ }^{1}$. Organizowanie środowiska uczenia się / środowiska edukacyjnego wiąże się zatem z projektowaniem różnorodnych sytuacji, w których dziecko jest autentycznie zaangażowane w proces uczenia się, ponieważ samodzielnie i w grupie bada, eksperymentuje, poszukuje, interpretuje, tworzy, dostrzega i rozwiązuje różne problemy, korzystając z posiadanych narzędzi

\footnotetext{
* Dr hab. Zuzanna Zbróg, Uniwersytet Jana Kochaniowskiego w Kielcach, Instytut Pedagogiki; e-mail: zzbrog@ujk.edu.pl.

1 W artykule używam zamiennie określeń „środowisko edukacyjne” i „środowisko uczenia się”, ponieważ „środowisko edukacyjne” rozumiem jako zespół zróżnicowanych elementów/czynników, które wiążą się z procesem uczenia się.
} 
kulturowych i możliwości, w tym np. potencjału kreatywności (np. Filipiak 2012; Bałachowicz 2016).

W tym artykule skoncentruję się na opisie - potwierdzonych empirycznie - cech środowiska edukacyjnego sprzyjającego ujawnianiu i rozwijaniu kreatywności dziecięcej we wczesnej edukacji.

\section{Metaanalizy - co wynika $\mathrm{z}$ kwerendy literatury}

Grupa angielskich badaczy przeanalizowała 210 publikacji naukowych na temat środowiskowych uwarunkowań umiejętności kreatywnych dzieci i młodzieży, które ukazały się na świecie w języku angielskim w latach 2005-2011 (Davies i in. 2013) ${ }^{2}$. Tylko 32 publikacje odpowiadały na pytanie: Jakie są dowody w literaturze na określenie kluczowych cech środowisk i warunków, które są najskuteczniejsze w promowaniu rozwoju umiejętności kreatywnych u dzieci i młodzieży?, z czego aż 19 badań dotyczyło „wydarzeń krytycznych” (critical events), a więc takich jak projekt lub doświadczenie, które są w jakiś sposób „wyjątkowe” lub inne niż codzienna praktyka ${ }^{3}$. Wyróżnienie tego typu działań na rzecz stworzenia lub poprawy niektórych uwarunkowań kreatywności uczniów ma o tyle znaczenie, że po zakończeniu projektu o charakterze „wydarzenia krytycznego” zajęcia powracają do tradycyjnego modelu i nie zmieniają zauważalnie codziennego środowiska uczenia się dzieci (Davies i in. 2013, s. 84). Odchodzenie od transmisyjnego paradygmatu edukacji, tradycyjnych strategii nauczania w kierunku edukacji opartej na aktywnym uczeniu się stymulującym myślenie kreatywne uczniów wymaga zatem trwałej modyfikacji środowiska uczenia się oraz codziennego dążenia do uwzględniania jednocześnie wszystkich cech środowiska promującego rozwój dziecięcej kreatywności ${ }^{4}$.

W wyniku rozległej kwerendy stwierdzono, potwierdzone empirycznie, znaczenie kilku czynników wspierających rozwój umiejętności kreatywnych u dzieci, które - dla jasności wywodu - sklasyfikowałam w dwie podstawowe grupy: środowisko

2 Odwołując się do wyników badań zanalizowanych w artykule Dana Daviesa i in. (2013, s. 84-87), nie przywołuję już licznych odniesień do konkretnych przypadków. Można je odnaleźć we wspomnianej publikacji.

3 Wyrażenie critical events w publikacji D. Daviesa i in. (2013) niesie ze sobą inne znaczenie niż critical incidents - „zdarzenia krytyczne”, polskim czytelnikom znane z książki Davida Trippa (1996).

4 W polskiej literaturze metaanalizy badań nad cechami środowiska kreatywnego przeprowadzili m.in. Edward Nęcka (2012) i Krzysztof J. Szmidt (2013; 2017; 2018), jednak w swoich wypowiedziach koncentrowali się oni głównie na licznych nurtach teoretycznych polskiej kreatologii oraz jej determinizmie społeczno-kulturowym, geograficznym, ekonomicznym i politycznym. Badacze ci odnosili się zatem do szerzej rozumianych uwarunkowań identyfikowania i stymulowania rozwoju twórczości człowieka. W tym artykule analizuję uwarunkowania tzw. minitwórczości skupiającej się na fenomenach obserwowanych w warunkach szkolnych i przedszkolnych. 
fizyczne i środowisko pedagogiczne. Należy jednak zaznaczyć, że wszystkie czynniki wzajemnie się przenikają i uzupełniają, co podkreślam, odwołując się w tekście do uprzednio opisanych determinantów. W artykule odnoszę się ponadto do wybranej polskiej literatury z obszaru wczesnej edukacji, w której od wielu lat zwraca się uwagę na znaczenie organizowania właściwego środowiska do uczenia się dzieci, w tym wspierania ich umiejętności kreatywnych.

\section{Środowisko fizyczne}

W obszarze środowiska fizycznego badacze wskazują na kilka znaczących czynników sprzyjających innowacyjnemu myśleniu i działaniu dzieci. Dotyczą one przede wszystkim elastycznego wykorzystania czasu i przestrzeni w sali (przed)szkolnej i poza nią (outdoor education) oraz dostępności różnorodnych materiałów.

\section{Elastyczne wykorzystanie przestrzeni}

Wiele badań dowodzi, że przestrzeń w klasie może być elastycznie wykorzystywana do stymulowania kreatywności uczniów. Ważne jest ogólne poczucie otwartości i przestronności w sali, co wiąże się np. z usuwaniem zbędnych mebli po to, aby umożliwić uczniom swobodne poruszanie się.

Na podstawie serii studiów przypadków w szkołach w Reggio Emilia wykazano znaczenie dla kreatywności cech sensorycznych w środowiskach edukacyjnych - światła, koloru, dźwięku, mikroklimatu. Rekomenduje się w związku z tym urządzanie sal, w których odbywają się zajęcia z dziećmi, jako serii „miniatelier”, akustycznie, a nie tylko wizualnie oddzielonych od reszty s a li, aby umożliwić uczniom cichą pracę w grupach.

W odpowiednio zorganizowanym środowisku uczenia się większość elementów znajdujących się w sali sprzyja samodzielnemu konstruowaniu wiedzy przez dzieci, indywidualnemu lub grupowemu tworzeniu, wyzwalaniu ciekawości dziecięcej, inspirowaniu do podejmowania różnych aktywności/działań, aby w konsekwencji wytworzyć pomysł czy rozwiązanie świadczące o wyzyskaniu własnego/zespołowego potencjału kreatywności ${ }^{5}$.

\section{Elastyczne wykorzystanie czasu}

Empirycznie dowiedziono, że kreatywności najlepiej służy nierygorystyczne korzystanie z czasu. Zwłaszcza małe dzieci, aby osiągnąć twórcze wyniki, potrzebują dłuższych okresów na zanurzenie się w działaniu. Niezwykle istotna jest praca we własnym tempie, bez presji. Zwiększenie czasu na zajęciach przeznaczonych na

5 Szerzej na temat podejmowania i twórczego rozwiązywania różnorodnych problemów przez dzieci w wieku przedszkolnym i wczesnoszkolnym piszę w innym artykule: Zbróg (2019). 
tworzenie skutkuje zwielokrotnieniem zainteresowania i zaangażowania w twórczą aktywność, co przekłada się na większą innowacyjność rozwiązań.

Inną ważną cechą środowiska fizycznego, stymulującą kreatywność uczniów, o której nie wspomina się w polskiej literaturze z zakresu wczesnej edukacji, jest pokaz prac w toku (in progress). Zwykle na wystawach umieszczane są skończone prace. Okazuje się jednak, że eksponowanie prac niedokończonych stymuluje wytwarzanie pomysłów i decyduje o tym, że ukończone po przerwie (np. następnego dnia) dziecięce dzieła zyskują na innowacyjności. Proces kreatywnego myślenia jest wydłużony, a wytwarzanie nowych rozwiązań odbywa się nawet wówczas, gdy dzieci celowo nie myślą o swojej pracy, a więc poza ich świadomością. Rozłożoną w czasie aktywnością podkreśla się ponadto, że dla uczestników pracy twórczej ważny jest proces tworzenia, a nie jego wynik.

Sukcesywne zagospodarowywanie przestrzeni sali (przed)szkolnej wytworami twórczości dziecięcej nie tylko odzwierciedla rozwój realizowanej tematyki, lecz także eksponuje kolejne etapy dochodzenia do ostatecznych rozwiązań. Na przykład zdjęcia z odgrywanych scenek czy prowadzonych doświadczeń wywołują spontaniczne zainteresowanie i pomysłowe komentarze w grupie współpracujących rówieśników.

\section{Dostępność odpowiednich materiałów}

Ze studiów przypadków w licznych placówkach wczesnej edukacji wiadomo, że zapewnienie dzieciom szerokiego wyboru odpowiednich materiałów, narzędzi i innych zasobów może stymulować kreatywność. Szczególnie ważna jest do stępność do wielu lekkich, prawie bezkształtnych materiałów, które $\mathrm{w}$ dziecięcych dłoniach mogą przybrać dowolną formę, takich jak glina, modelina, plastelina, pianka modelarska, drut, celofan, bibułka, piasek itp. Z kącika zajęć technicznych dobrze jest usunąć gotowe klocki i zastąpić je sznurkami, styropianem, puszkami, pudłami i innymi opakowaniami (zob. np. Guz 2015, Tijnagel-Schoenaker 2017).

Dostęp do nowych mediów i technologii sprzyja rozwijaniu kreatywności głównie uczniów starszych i młodzieży wykluczonej społecznie, a także dorosłych. Jednak możliwość korzystania z tablic interaktywnych wspiera w rozwijaniu umiejętności twórczych uczniów młodszych z lepszą pamięcią wzrokową, a ponadto zwiększa u wszystkich uczniów klas I-III możliwości odkrywania i wyobrażania sobie możliwych rozwiązań, nawet jeśli zajęcia dotyczą takich podstawowych aktywności, jak czytanie czy liczenie.

\section{Uczenie się poza szkołą/przedszkolem}

Uczenie się poza salą szkolną czy przedszkolną, w środowisku naturalnym, sprzyja twórczemu rozwojowi dzieci. Jak dowiedziono w studium przypadku szkoły 
podstawowej, która współpracowała $\mathrm{z}$ architektami krajobrazu w celu przekształcenia jej przestrzeni zewnętrznej, działając na zewnątrz, dzieci czuły się „właścicielami" czasu i przestrzeni, co sprzyja wytwarzaniu innowacyjnych pomysłów.

Badacze zauważyli ponadto dużą wartość zewnętrznych środowisk kreatywnych, które w szkołach szkockich i norweskich dotyczą tzw. „leśnych szkół”, jednak ich cechy mogą być przenoszone na inne środowiska zewnętrzne 6 . Cechy szkół leśnych jako „środowisk kreatywnych” obejmują:

- zastosowanie lokalnego lasu (a więc „dzikiego”, naturalnego środowiska przyrodniczego);

- $\quad$ regularny, częsty kontakt w tym samym otoczeniu przez dłuższy czas;

- zapewnienie swobody odkrywania przy użyciu wielu zmysłów i wielorakich inteligencji;

- zadbanie o czas i przestrzeń dla rozpoznania i pielęgnowania indywidualnych stylów uczenia się;

- zmniejszenie stosunku liczby uczniów do liczby dorosłych - dzieci najczęściej pracują w parach lub grupach, a więc nauczyciel ma jednorazowo pod swoją wspierającą uwagą niewielką grupę, co sprzyja m.in. owocnemu dialogowi.

Uczenie się w naturalnym środowisku niesie ze sobą szereg innych wartości: „Procesy wspólnej uwagi z rówieśnikami i dorosłymi - łączenie sfery fizycznej i społecznej, wzmocnione emocjami - uwydatniają zdolności wyodrębniania nowych informacji z otoczenia i zachowania się w określonym kontekście. Uczenie się skoordynowania działań społecznych, np. podczas budowania szałasu, gry w piłkę czy wchodzenia na drzewa, od razu uwypukla wartości relacyjne, uczy roztropności i swobodnego działania" (Bałachowicz 2017, s. 67). Wszystko to stanowi o uznawaniu danego środowiska za stymulującego kreatywność.

Do wymienionych zalet uczenia się poza salą (przed)szkolną należy dodać wolność uczenia się przy wykorzystaniu skarbnicy „luźnych części” (kamyki, patyki, gałęzie, trawy, piasek), z zarządzaniem własnym działaniem i przestrzenią do odkrywania różnych możliwości i sposobów uczenia się.

Korzystanie z innych środowisk poza szkołą/przedszkolem, w tym z a b i e r a n i e dzieci do muzeów, galerii, filharmonii, zwiększa uczniowskie umiejętności kreatywne. Wyniki badań dowodzą jednak, że największe znaczenie dla zwiększenia aktywności dziecięcej i tym samym stwarzania uczniom młodszym kreatywnego środowiska uczenia się ma rzeczywiste, długofalowe partnerstwo z instytucjami zewnętrznymi, zaangażowanie w działalność grup sportowych czy

6 Przykłady pokazujące możliwość przełożenia norweskich założeń do polskiej praktyki edukacyjnej zawiera zeszyt nr 4 „Nauczania Początkowego” z roku 2016/2017 pt. Uczenie się poza klasa szkolna - edukacja przyrodnicza, pod red. Mirosławy Parlak i Anny Witkowskiej-Tomaszewskiej. Teoretyczne założenia edukacji przyrodniczej w Norwegii zostały opublikowane zarówno w tym numerze, jak i w monografii: Bałachowicz i in. (2015). 
artystycznych oraz różnego typu stowarzyszeń. W organizacjach pozaszkolnych dzieci mają możliwość obserwowania przykładów innowacyjnych praktyk, prowadzenia rozmów $\mathrm{z}$ kreatywnymi specjalistami z różnych obszarów: $\mathrm{s}$ p o r to w cami, artystami, biznesmenami, urzędnikami itp. Dla uzyskania długoterminowego oddziaływania kreatywnych środowisk pozaszkolnych ważna jest stała wymiana praktyk i wiedzy. Wyniki badań świadczą ponadto o tym, że „nieformalne” przestrzenie posiadają zasoby twórcze (ludzkie i materialne), które nie tylko pomagają stymulować kreatywność, ale także zwiększają dziecięce zaangażowanie i motywację do wytwarzania innowacyjnych rozwiązań.

\section{Środowisko pedagogiczne}

W ramach tworzenia odpowiedniego dla rozwoju dziecięcej kreatywności środowiska pedagogicznego za najważniejsze uznaje się całościowe spojrzenie na dziecko, jego potrzeby i zasoby, w tym posiadany potencjał twórczy, za którego ujawnienie i aktywizację odpowiada nauczyciel.

\section{Nieprecyzyjne planowanie}

Zdolność nauczycieli dospontanicznego działania i zmiany planó w uznawana jest za jeden $\mathrm{z}$ ważniejszych czynników modelowania kreatywnego środowiska uczenia się. Badania wykazały, że tam, gdzie dzieci mają pewną kontrolę nad własnym uczeniem się i są one wspierane w podejmowaniu ryzyka, z właściwą równowagą między wykonywaniem zadań ustrukturyzowanych a wolnym wyborem sposobu rozwiązania zadań, ich kreatywność jest zwiększona.

Wyzwalanie potencjału kreatywnego wymaga zatem odejścia od planowania zajęć i poszukiwania systemów, które przygotowują dzieci do wspólnego myślenia. Uznaje się bowiem, że kreatywność wyrasta $\mathrm{z}$ wielu zespołowych doświadczeń połączonych z dbałością o wspieranie rozwoju zasobów osobistych każdego dziecka. Dokładniej wyjaśnia tę zależność Józefa Bałachowicz (2017, s. 64), która zauważyła, że „[d]zięki współpracy i bogaceniu własnych doświadczeń dziecko zyskuje dostęp do zasobów kultury, jej systemów wiedzy, wartości i narzędzi poznania, a to z kolei daje mu możliwość wykorzystania i rozwoju psychicznych i duchowych potencjałów młodego człowieka”, w tym potencjałów twórczych.

Mimo nacisku na swobodę wyrażania siebie uczniowie w późnym wieku wczesnoszkolnym (9-10 r.ż.) potrzebują także wspierającego i jednocześnie zorganizowanego środowiska. Zapewnienie „bezpiecznej” struktury wykonywania zadań wydaje się być szczególnie ważne w celu umożliwienia uczniom podejmowania ryzyka, kreatywnego i krytycznego myślenia oraz zadawania pytań. Badacze uważają, że kreatywności w tym wieku najlepiej służy rów now a g międ zy pracą ustrukturyzowaną a nieustrukturyzowaną. 


\section{Uczenie się oparte na grach i zabawach}

Rola gier i zabaw we wczesnej edukacji jest dobrze udokumentowana, jednak rzadziej dowodzi się ich dużego znaczenia również we wspieraniu rozwoju umiejętności kreatywnych. Podejście elastyczne, nieformalne, pozwalające uczniom pracować we własnym tempie, bez presji czasowej, z pewną dozą autonomii ucznia - jak dowodzi kilka badań - znacząco zwiększa kreatywność uczniów. Zarówno na terenie klasy szkolnej, jak i w środowisku pozaszkolnym znajdują się różnego rodzaju pomoce lub przedmioty, które mogą służyć dzieciom do uczenia się w trakcie zabawy. Wspólne swobodne zabawy nie tylko wspomagają rozwój umiejętności współdziałania u dzieci, lecz także sprzyjają tworzeniu: wymyślaniu nowych zabaw, gier, negocjowaniu, rozwiązywaniu rówieśniczych konfliktów i problemów - intensywnie wspierają rozwój nie tylko poznawczy i fizyczny, lecz także społeczno-emocjonalny.

Swobodna zabawa w gronie rówieśników stwarza liczne okazje do rozwijania dziecięcych zainteresowań, wyobraźni i przedstawiania rówieśnikom oryginalnych pomysłów, a także do przeżywania radości z tworzenia niecodziennych rozwiązań. W badaniach podkreśla się zresztą ogromne znaczenie radości i o gólne go poczucia hu moru dla wyzwalania potencjału kreatywnego podczas twórczej pracy, np. o charakterze twórczości językowej’. Także z polskich badań wiadomo, że jedną z cech osobowości twórczej u szczególnie uzdolnionych dzieci jest oryginalne i spontaniczne poczucie humoru (Bonar 2008, s. 38-41; Kuszak 2018/2019).

\section{Uwzględnianie dziecięcych potrzeb}

Sprzyjające ujawnianiu się i stymulowaniu umiejętności kreatywnych środowisko pedagogiczne wiązane jest w badaniach także z uzwględnianiem potrzeb dziecięcych. Wymienia się wśród nich głównie potrzebę wolności wyboru (tematyki zajęć, zadań, sposobów rozwiązania), wolności od presji (czasowej, wygórowanych oczekiwań, oceniania), potrzebę współdziałania i zabawy z rówieśnikami, potrzebę autonomii ${ }^{8}$.

Ważne jest w tym kontekście odchodzenie od narzucania przez nauczyciela ściśle określonych (np. programem nauczania, podręcznikiem) obszarów tematycznych, aby zapewnić dzieciom większą swobodę w wyborze tematyki, którą chcą się

7 „Dzieci są niezrównanymi kreatorami światów, zatem rozszyfrowują kreację poetycką za pomocą fantazji, radości i zmysłu humoru" (Książek-Szczepaniakowa 1994, s. 34).

8 W książce pt. Identyfikowanie i zaspokajanie potrzeb społecznych w niepublicznych szkołach podstawowych na podstawie badań empirycznych na pełnej próbie uczniów z województwa świętokrzyskiego wykazałam, że uczniowie klas I-III odczuwają niedosyt w wyrażaniu dziecięcych potrzeby podmiotowego traktowania odnoszącej się do sfery wolności do dialogu, swobody wyboru ofert, współuczestniczenia w decydowaniu o sobie i swoim miejscu w szkole, a także wolności od krytyki (Zbróg 2011, s. 134-136). 
zajmować i która jest ich „mocną stroną”. Nie chodzi przy tym wyłącznie o większą swobodę dla dziecięcej wyobraźni, ale przede wszystkim o p o c z u cie p od mio towości, autonomii, o możliwość decydowania o sobie i tym, czego będę się uczyć i w jaki sposób. Ma to kluczowe znaczenie dla rozwijania indywidualnych „zasobów i możliwości uczenia się” (Bałachowicz 2017, s. 75). Ustalanie znaczeń w świecie życia codziennego wiąże się bowiem z takimi kompetencjami, jak: „umiejętność współpracy w grupie, prowadzenia dyskusji, negocjacji, umiejętność rozwiązywania konfliktów, kreatywne działanie, zdolność do samoorganizowania się, samorządność” (Bałachowicz 2017, s. 73).

\section{Podmiotowe relacje między nauczycielami a uczniami}

Ze świadomością dziecięcych potrzeb ściśle wiąże się elastyczność w relacjach pedagogicznych. Dialog wydaje się być kluczem do pojawienia się takiej relacji (Michalski 2016). Oddanie głosu dzieciom, uznawanie ich racji, wsłuchiwanie się $\mathrm{w}$ ich sposoby argumentowania decyduje także o ich zaangażowaniu w rozumienie siebie, innych i otaczającego świata, o pojawieniu się u uczniów najmłodszych poczucia ważności wyrażanych poglądów i zgromadzonych doświadczeń. Dzięki rozmowom z uczniami nauczyciel ma szansę się dowiedzieć, w jaki sposób dzieci postrzegają świat, co myślą o danej kwestii, czy też, jakie są ich przekonania na określony temat. Zyskuje on przekonanie, że efekty uczenia się, mimo iż są ograniczone celami, bywają nieprzewidywalne i zindywidualizowane.

Ważną i niepodważalną cechą wspierającego kreatywność środowiska pedagogicznego jest zatem pełna szacunku relacja między nauczycielem a uczniami. Ze studiów przypadków dotyczących praktyk w Reggio Emilia wynika, że kreatywność zależy od oczekiwań nauczycieli i innych osób oraz od sposobu, w jaki dzieci postrzegają te oczekiwania. Jeśli nauczyciele oczekują od dzieci innowacyjnych rozwiązań, dzieci starają się korzystać ze swojego twórczego potencjału. Jeśli uczniowie czują, że nauczyciel z niechęcią odnosi się do ich niestandardowych pomysłów, ich kreatywność nie jest uruchamiana9.

Badacze zaobserwowali ponadto, że rozmowy między dziećmi a nauczycielami stanowią ramy wspierające wspólną pracę. Regularnie praktykowa ny dialog podtrzymuje społeczność, która myśli razem. Z badań wynika, że najbardziej sprzyjają kreatywności interakcje - wymiana międzyludzka, przy czym decydującymi elementami są: ne gocjowanie konfliktów oraz porównywanie, głośne omawianie czy téz dyskutowanie nad pomysłami i działaniami.

9 Takie same wnioski wynikają z badań przeprowadzonych wśród studentek pedagogiki przedszkolnej i wczesnoszkolnej, uczestniczących w praktykach pedagogicznych (Zbróg 2014, S. $256-257)$. 
Oprócz wspierających relacji z nauczycielami istnieją mocne dowody, co wynika z badań, na to, że kreatywność uczniów jest ściśle związana z możliwością ws półpracy z rówieśnikami - obecność wspólnych działań jest istotną cechą środowiska twórczego, przy czym współpraca uczniów jest bardziej prawdopodobna na zewnątrz niż w klasie. Wewnątrz klasy praca koncentruje się zwykle na indywidualnym ukierunkowaniu uczniów, podczas gdy na zewnątrz zajęcia edukacyjne częściej wymagają współpracy między uczniami.

Zauważono ponadto, że ju ż sama działalność o charakterze twórczym powoduje lepszą współpracę między dziećmi, promuje sytuacje wyzwalające innowacyjne pomysły oraz inicjuje wymianę myśli.

\section{Rekomendacje dla praktyki we wczesnej edukacji}

Irena Adamek i Józefa Bałachowicz (2013, s. 249) w podsumowaniu badań na temat kompetencji kreatywnych nauczycieli wczesnej edukacji stwierdziły, że „nawet jeśli [nauczyciele - przyp. Z.Z.] cenią twórcze postawy u swoich uczniów, to mają małe umiejętności tworzenia warunków do ich rozwoju. W wypowiedziach często podkreślają, że brakuje im w procesie dokształcania możliwości doskonalenia kompetencji kreatywnych". Badani nauczyciele nie wiedzą zatem, jak wykorzystywać własny potencjał kreatywności do organizowania środowiska uczenia się sprzyjającego stymulowaniu kreatywności u dzieci.

Zarówno analizy prowadzone pod kierunkiem I. Adamek i J. Bałachowicz (2013), jak i badania własne (Zbróg 2014) pokazują, że kreatywność jako potencjał twórczy, który bywa ujawniony przez jednostkę, może również - jak zauważyła Katarzyna Krasoń (2011, s. 10) - pozostać „niespełnioną obietnicą”. Wyzwalanie u dzieci kreatywności wymaga bowiem podejmowania świadomych i systematycznych działań pedagogicznych, zmieniających model wczesnej edukacji i dominujące w niej praktyki edukacyjne.

W polskiej literaturze pedagogicznej od kilkudziesięciu lat podkreśla się konieczność zwrócenia się ku „edukacji otwartej, elastycznej, transformatywnej, nastawionej na społeczne i kreatywne uczenie się" (Bałachowicz 2017, s. 45). Wyniki anglojęzycznych empirycznych badań naukowych na temat oddziaływania organizowanego przez nauczycieli środowiska uczenia się na rzecz wzbudzania i rozwijania umiejętności kreatywnych u dzieci, mogą stanowić podstawę rekomendacji dla nauczycieli także w polskich szkołach i przedszkolach. Najważniejsze z nich można zebrać w kilku punktach ${ }^{10}$ :

1. Z metaanaliz wynika, że wiele kreatywnych prac w szkołach wiąże się ze specjalnymi, jednostkowymi inicjatywami (np. projekty, tygodnie tematyczne, praca $\mathrm{z}$ podmiotami zewnętrznymi), które zmieniają bieżącą praktykę tylko

10 Odwołuję się do wybranych rekomendacji z artykułu: Davies i in., 2013, s. 89 oraz do ustaleń z innych badań. 
tymczasowo. Z tego powodu ważne jest skoncentrowanie się na codziennym organizowaniu kreatywnego środowiska uczenia się.

2. Środowisko sprzyjające kreatywności znacznie poprawia się w wyniku długotrwałej współpracy ze środowiskami zewnętrznymi, instytucjami i organizacjami społecznymi, kulturalnymi, sportowymi, placówkami artystycznymi itp. oraz kreatywnymi specjalistami z różnych obszarów funkcjonowania człowieka w codziennym świecie.

3. Jakakolwiek presja zewnętrzna (np. czasowa, co do osiągnięć, ocen) nie służy kreatywności. Należy zatem podkreślić wagę skupiania się nie na wynikach, ale na procesach wyzwalających potencjał kreatywności i umiejętności tworzenia.

4. Kreatywności pomaga elastyczne korzystanie z czasu i przestrzeni fizycznej (sali, naturalnego środowiska poza szkołą czy przedszkolem, dostępność do wielu zwykłych materiałów) oraz nierygorystyczne, nieprecyzyjne planowanie. Cenna jest spontaniczność nauczyciela oraz jego ogólne poczucie humoru.

5. Rozmowy, dialog relacyjny nauczyciela z dziećmi, postawa pełna szacunku, dbałości o identyfikowanie i zaspokajanie dziecięcych potrzeb nie tylko sprzyjają tworzeniu odpowiedniego środowiska dla kreatywnego myślenia i działania, lecz także pozwalają dzieciom zachować większą kontrolę nad własnym uczeniem się, zwłaszcza zadbać o czas na wypracowywanie indywidualnie skutecznych strategii uczenia się.

6. Uczenie się we współpracy z rówieśnikami, zwłaszcza podczas gier i zabaw, wspólne negocjowanie znaczeń w parach lub grupach, uczenie się jeden od drugiego samo w sobie decyduje o intensywnym wytwarzania różnych pomysłów i rozwiązań.

\section{Podsumowanie}

W literaturze dotyczącej przedmiotu badań podkreśla się znaczenie kilku kluczowych cech środowiska edukacyjnego (fizycznego i pedagogicznego), które wspierają rozwój umiejętności kreatywnych dzieci w wieku przedszkolnym i wczesnoszkolnym. Zostały one szczegółowo omówione w artykule, warto jednak podkreślić, że metaanalizy wskazują na jeszcze inne zalety środowiska sprzyjającego kreatywności dziecięcej, np.: zwiększenie motywacji i zaangażowania w proces uczenia się, rozwój umiejętności społecznych, emocjonalnych i myślenia w trakcie wprowadzania codziennej pracy w małych zespołach, a nawet - poprawę frekwencji szkolnej.

Kwerenda anglojęzycznych badań dostarczyła dowodów także na to, że organizowanie przez nauczycieli środowiska uczenia się wspierającego kreatywność jest możliwe i niesie ze sobą wiele korzyści zarówno dla dzieci, jak i nauczycieli. Z jednej strony powoduje zwiększenie osiągnięć uczniów, a z drugiej - oddziałuje na rozwój 
profesjonalizmu nauczycieli, którzy podejmując szereg działań na rzecz dzieci, jednocześnie doskonalą swoje kompetencje pedagogiczne w obszarze kreatywności.

\section{Bibliografia}

Adamek I., Bałachowicz J. (2013). Zakończenie. W: Kompetencje kreatywne nauczycieli wczesnej edukacji dziecka. Adamek I., Bałachowicz J. (red.), Kraków: Oficyna Wydawnicza „Impuls”.

Bałachowicz J. (2016). Paradoksy przemian współczesnej edukacji dziecka. W: Zrozumieć szkołę. Konteksty zmiany. Szymański M. J., Walasek-Jarosz B., Zbróg Z. (red.), Warszawa: Wydawnictwo APS.

Bałachowicz J. (2017). Szkoła jako przestrzeń budowania przyszłości. W: Zrozumieć uczenie się. Zmienić wczesną edukację. Bałachowicz J., Korwin-Szymanowska A., Lewandowska E., Witkowska-Tomaszewska A., Warszawa: Wydawnictwo APS.

Bałachowicz J. (2018/2019). Poznawcze i społeczne wymiary projektowania środowiska skutecznego uczenia się dzieci. „Edukacja Wczesnoszkolna”, nr 4, s. 7-20.

Bałachowicz J., Halvorsen K. V, Witkowska-Tomaszewska A. (2015). Edukacja środowiskowa $w$ kształceniu nauczycieli. Perspektywa teoretyczna. Warszawa: Wydawnictwo APS.

Bonar J. (2008/2009). Humor a twórczość, czyli dlaczego należy cenić uczniowskie poczucie humoru. „Nauczanie Początkowe. Kształcenie Zintegrowane”, nr 2.

Davies D., Jindal-Snape D., Collier C., Digby R., Hay P., Howe, A. (2013). Creative learning environments in education: A systematic literature review. „Thinking Skills and Creativity", 8, s. 8o-91.

Filipiak E. (2012). Rozwijanie zdolności uczenia się. Z Wygotskim i Brunerem w tle. Sopot: GWP.

Guz S. (2015). Edukacja w systemie Marii Montessori. Wybrane obszary kształcenia. T. 1. Lublin: Wydawnictwo UMCS.

Krasoń K. (2011). Skala Postaw Twórczych versus Odtwórczych (SPTO). Podręcznik do testu w wersji dla szkoły podstawowej klas I-III. Kraków: Krakowskie Towarzystwo Edukacyjne.

Książek-Szczepaniakowa A. (1994). Dobro „po niczemu”... W: Dziecko i jego światy w poezji dla dzieci. Chęcińska U. (red.). Szczecin: Książnica Szczecińska.

Kuszak K. (2018/2019). Dyspozycje małego ucznia do obcowania z poezją. „Edukacja Wczesnoszkolna", nr 1, s. 7-22.

Michalski J. (2016). Relacyjność jako kategoria pedeutologiczna. W: Zrozumieć szkołę. Konteksty zmiany. Szymański M. J., Walasek-Jarosz B., Zbróg Z. (red.). Warszawa: Wydawnictwo APS.

Nęcka E. (2012). Psychologia twórczości. Sopot: GWP.

Szmidt K. J. (2013). Pedagogika twórczości. Sopot: GWP.

Szmidt K. J. (2017). Edukacyjne uwarunkowania rozwoju kreatywności. Łódź: Wydawnictwo UŁ. 
Szmidt K.J. (2018). Teoretyczno-badawcze nurty w polskiej kreatologii. „Nauki o Wychowaniu. Studia Interdyscyplinarne", t. 7, nr 2, s. 8-43.

Tijnagel-Schoenaker B. (2017). The Reggio Emilia Approach... The Hundred Languages. „Prima Educatione”, nr 1, s. 139-146.

Tripp D. (1996). Zdarzenia krytyczne w nauczaniu. Warszawa: WSiP.

Zbróg Z. (2011). Identyfikowanie i zaspokajanie potrzeb społecznych w niepublicznych szkołach podstawowych. Kraków: Oficyna Wydawnicza Impuls.

Zbróg Z. (2014). Studentki o nowatorstwie pedagogicznym we wczesnej edukacji analiza opinii z perspektywy teorii atrybucji. W: Pomiędzy dwiema edukacjaminauczyciel wczesnej edukacji wobec czasu zmiany. Adamek I., Olszewska B. (red.). Łódź: Wydawnictwo WSP.

Zbróg Z. (2019). Rozwijanie dziecięcej kreatywności w procesie uczenia się rozwiązywania problemów. „Prima Educatione”, nr 3, s. 97-110.

\title{
ORGANIZING AN EDUCATIONAL ENVIRONMENT TO ENJOY DISCLOSURE AND DEVELOP CHILDREN'S CREATIVITY
}

\begin{abstract}
This article analyzes the most important factors supporting the development of creative skills in preschool and early education children, which were selected on the basis of empirical research from the last few years. For the sake of clarity they were divided into two groups: the physical environment and the pedagogical environment, although all the determinants presented intertwine and complement each other. Finally, selected solutions for early childhood education were recommended.
\end{abstract}

Keywords: creativity; educational environment; early childhood education. 